\title{
NUMERICAL ANALYSIS OF THE EFFECT OF INITIAL PLASTICITY ON TRANSIENT CREEP IN COMPACT TENSION SPECIMEN UNDER MECHANICAL LOAD
}

\author{
Marko Katinić, Dražan Kozak, Pejo Konjatić
}

Original scientific paper

The effect of initial plasticity on transient creep in plain strain compact tension $C(T)$ specimen under load control is numerically analyzed in this paper. The detailed finite element (FE) analysis was performed by varying the magnitude of the initial step-load, and for general material properties where different plastic and creep stress exponents were systematically varied. Comparisons have been performed between the FE computed $C(t)$ values and available estimation equation. It has been found that the estimation equation provides good agreement with the FE results.

Keywords: $C(t)$ integral; $C(T)$ specimen; initial plasticity; load control; transient creep

\section{Numerička analiza utjecaja početne plastičnosti na tranzijentno puzanje kompaktne vlačne epruvete pod mehaničkim opterećenjem}

Izvorni znanstveni članak

U ovome radu numerički je analiziran utjecaj početne plastičnosti na tranzijentno puzanje kompaktne vlačne epruvete u stanju ravninske deformacije pri kontroli opterećenja. Detaljna analiza metodom konačnih elemenata (MKE) provedena je variranjem veličine početnog koraka opterećenja i za opća svojstva materijala u kojima su sustavno mjenjani eksponenti plastičnosti i puzanja. Izvršene su usporedbe između $C(t)$ vrijednosti izračunatih MKE i dostupnom jednadžbom procjene. Utvrđeno je da jednadžba procjene osigurava dobro slaganje s rezultataima MKE analize.

Ključne riječi: $C(T)$ epruveta; $C(t)$ integral; kontrola opterećenja; početna plastičnost; tranzijentno puzanje

\section{Introduction}

Creep crack growth should be considered in a residual life assessment for defective components operating at elevated temperature. The creep crack growth rate is correlated with the amplitude of the singular stress and strain fields at the crack tip, denoted by timedependent parameter $C(t)$. For elastic-power law creep cases, the value of $C(t)$ satisfies two asymptotic behaviors. At short times $(t \rightarrow 0), C(t)$ is singular and satisfies the following relationship:

$C(t)=\frac{K_{\mathrm{I}}^{2}}{(n+1) \cdot E^{\prime} \cdot t}$

At long times $(t \rightarrow \infty)$ parameter $C(t)$ approaches its steady-state value denoted by $C^{*}$. By simple interpolation, Riedel [1] proposed an estimation equation for $C(t) / C^{*}$. Later, Ainsworth and Budden [2] developed another, slightly different approximation of this relationship. In both cases, $C(t)$ converges to $C^{*}$ as $t \rightarrow \infty$. However, initial widespread plasticity at the crack tip invalidates this approach for estimation of $C(t)$. For elastic-plastic-creep problems, Joch and Ainsworth [3] proposed an estimation equation for $C(t)$, by extending the elastic-creep analysis [2]. Using finite element method (FEM), they analyzed the effect of plasticity on the magnitude of $C(t)$ during the transition phase of creep. Due to the effect of plasticity, $C(t)$ is bounded as $t \rightarrow 0$, and reduces in magnitude with increasing level of plasticity. However, their estimation equation for $C(t)$ is valid only for the case of equal stress exponents for creep and plasticity. Generally, these stress exponents are unequal for real materials. Therefore, it was necessary to modify the existing equation for estimation of $C(t)$ at general stress exponent cases. Lee et al. [4] proposed estimation equation of transient $C(t)$ for general elasticplastic-creep conditions under load and displacement control. The proposed equations have been derived by modifying plasticity-correction term in the existing equations. Validation of these new equations has been performed using elastic-plastic-creep FE analysis results for plain strain single-edge-cracked bend $S E(B)$ specimen.

This paper reports results of elastic-plastic-creep FE analysis for plain strain compact tension $C(T)$ specimen under load control. The analysis was carried out with systematic variation of the stress exponents of creep and plasticity laws. The proposed general equation for estimation of transient $C(t)$ [4] is validated by comparison with the results of the $\mathrm{FE}$ analysis.

\section{Numerical analysis}

\subsection{Geometric and loading conditions}

Two-dimensional high crack-tip constrained plain strain $C(T)$ specimen was considered, as described in Fig. 1.

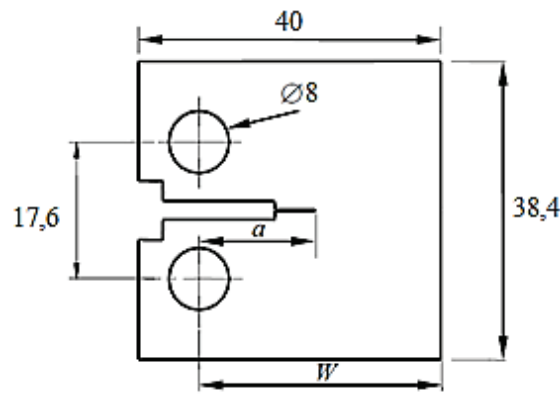

Figure1 CT specimen used for analysis

The width of specimen was selected to be $W=32 \mathrm{~mm}$ with the relative crack depth $a / W=0,5$. The effect of the level of initial plasticity on transient creep is analyzed by 
systematically varying the magnitude of the initial stepload. The load was normalized with respect to the plastic limit load per unit thickness $P_{\mathrm{L}}$. The ratio of the applied load to the limit load $L_{\mathrm{r}}=P / P_{\mathrm{L}}$ reflects the proximity to plastic collapse. Three values of loading magnitude were considered in this paper: $L_{\mathrm{r}}=0,4 ; 0,8$ and 1,0 .

\subsection{Material properties}

The material properties for elastic-plastic analysis were expressed by the following relationship:

$$
\varepsilon=\varepsilon^{\mathrm{e}}+\varepsilon^{\mathrm{p}}=\frac{\sigma}{E}+0,002 \cdot\left(\frac{\sigma}{\sigma_{0}}\right)^{m}=\frac{\sigma}{E}+A \cdot \sigma^{m},
$$

where $\varepsilon, \varepsilon^{\mathrm{e}}, \varepsilon^{\mathrm{p}}$ are total, elastic and plastic strain, respectively; $\sigma$ is stress; $A$ and $m$ are material constants. The yield strength $\sigma_{0}=400 \mathrm{MPa}$, Young's modules $E=$ $200 \mathrm{GPa}$, and Poisson's ratio $v=0,3$ were used for all analyzed cases with two strain hardening exponent values, $m=5$ and 10. It has been shown that the equation (2) is the most suitable material model for this FE analysis [5]. Power-law creep with material constants $B$ and $n$ was used for creep analysis in this paper:

$\dot{\varepsilon}^{\mathrm{c}}=B \cdot \sigma^{n}$,

where $\dot{\varepsilon}^{\mathrm{c}}$ denotes creep strain rate. The following values of material constants were considered: $B=4 \times 10^{-16}$ $(\mathrm{MPa})^{-n} \mathrm{~h}^{-1}$ for $n=5$ and $B=1 \times 10^{-26}(\mathrm{MPa})^{-n} \mathrm{~h}^{-1}$ for $n=$ 10. These values of constant $B$ do not have any influence on the results as these are given in a normalized form.

\subsection{Finite element analysis}

Elastic-creep and elastic-plastic-creep FE analyses of the $C(T)$ specimen geometry in Fig. 1 are performed using the general-purpose FE program, ABAQUS [6]. Due to the symmetry, only a half of $C(T)$ specimen was modeled. A small geometry change continuum FE model was employed in these analyses. Eight-node reduced integration elements for two-dimensional, plain strain problems (CPE8R) were used in order to avoid problems associated with incompressibility. The elements of innermost ring at the crack tip are degenerated into triangles. The three nodes along one side of the eightnode element are defined so that they share the same geometrical place. Each of the three collapsed nodes can be displaced independently. Fig. 2 shows the FE mesh for the $C(T)$ specimen, which has 2484 elements and 7686 nodes.

The load is applied to the load hole using the multipoint constrain (MPC) option within ABAQUS. Initially the load was firstly applied instantaneously to the FE model using an elastic or elastic-plastic calculation (at time $t=0)$. The load was then held constant and subsequent time-dependent creep calculation was performed. For time-dependent creep calculations, a combined implicit and explicit method was selected within ABAQUS for numerical efficiency. With the load held constant, subsequent creep deformation causes a relaxation of the crack-tip stresses until a steady-state stress distribution is reached. The transient state stress is characterized by path-dependent $C(t)$ integral, and steadystate stress is characterized by path-independent integral $C^{*}$.

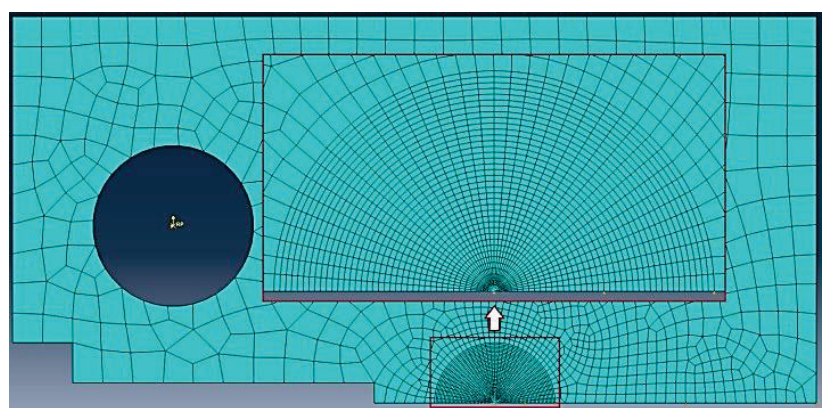

Fig. 2 Typical mesh in FE model for the $C(T)$ specimen

To gain confidence in the present FE analysis, elastic and elastic-creep analyses were performed. Tab. 1 compares results of $\mathrm{FE}$ stress intensity factor $K_{\mathrm{I}}$ and $C^{*}$ values with analytical solutions for $C(T)$ specimen geometry $[7,8]$ and provides confidence in the present FE analyses for elastic and steady state creep conditions.

Table 1 Ratios of the FE $K_{\mathrm{I}}$ and $C^{*}$ with analytical solutions $[7,8]$

\begin{tabular}{|c|c|c|}
\hline$K_{\mathrm{I}}(\mathrm{FE}) / K_{\mathrm{I}}[7]$ & & 1,002 \\
\hline \multirow{2}{*}{$C^{*}(\mathrm{FE}) / C^{*}[8]$} & $n=5$ & 0,973 \\
\cline { 2 - 3 } & $n=10$ & 0,980 \\
\hline
\end{tabular}

Further confidence in the FE model is gained by checking asymptotic behavior of the $C(t)$ values at very short times. Under transient creep conditions $\mathrm{FE} C(t)$ integral value shows singular behavior, and is sensitive to mesh fineness. Since the $C(t)$ integral should be calculated close to the crack tip, its value was determined by simply taking the second contour value [9]. At short times, the $C(t)$ value should follow Riedel's estimation equation for $C(t) / C^{*}$ [1]. Fig. 3 depicts the present FE results for elastic-creep calculations in $\log \left[(n+1) \cdot C(t) / C^{*}\right]$ versus $\log \left(t / t_{\text {red }}\right)$ space, confirming the correct asymptotic behavior.

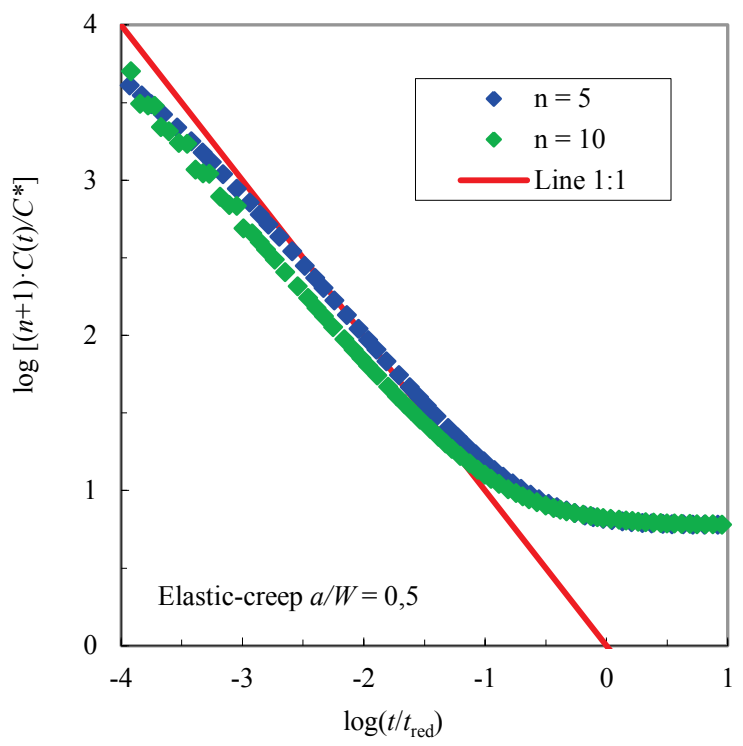

Figure3 Validation for $C(t)$ value with creep exponenet $n=5$ and 10 


\section{Transient $C(t)$ estimation equations}

For elastic-creep conditions under load control, Riedel [1] proposed the following equation:

$$
\frac{C(t)}{C^{*}}=1+\frac{1}{(n+1)} \cdot \frac{t}{t_{\mathrm{red}}}=1+\frac{\tau}{(n+1)},
$$

where $\tau$ is the normalized time which is given in terms of redistribution time $t_{\text {red }}$ as follows:

$$
\tau=\frac{t}{t_{\mathrm{red}}}=\frac{C^{*} \cdot t}{J(0)}
$$

Here $J(0)$ denotes the FE value of $J(t)$ at $t=0$.

Ainsworth and Budden [2] developed another equation for estimation of transient $C(t)$ under elasticcreep load control conditions as follows:

$$
\frac{C(t)}{C^{*}}=\frac{(1+\tau)^{n+1}}{(1+\tau)^{n+1}-1},
$$

For elastic-plastic-creep conditions under load control, Joch and Ainworth [3] proposed an estimation formula for transient $C(t)$ which takes into account the effect of the initial plasticity:

$$
\frac{C(t)}{C^{*}}=\frac{(1+\tau)^{n+1}}{(1+\tau)^{n+1}-\phi} .
$$

The parameter $\phi$ reflects the influence of initial plasticity on $C(t)$, and is defined by:

$$
\phi=1-\frac{A \cdot C^{*}}{B \cdot J(0)}
$$

However, the Eq. (8) is valid only for equal stress exponents for plasticity and creep, $m=n$. Lee et al. [4] proposed estimation equation for transient $C(t)$ for general elastic-plastic-creep conditions where the plastic and creep exponents can be also different. In the case of load control this equation is as follows:

$$
\begin{array}{r}
\frac{C(t)}{C^{*}}=\frac{(1+\tau)^{n+1}}{(1+\tau)^{n+1}-\phi^{\prime}} \text { with } \phi^{\prime}=1-\left(\frac{F}{D}\right)^{n+1} \\
\left(\text { If } \phi^{\prime}<0 \text { than } \phi^{\prime}=0\right)
\end{array}
$$

$D$ and $F$ values denote the normalized opening stress at $t$ $=0$ (initial conditions) and the normalized opening stress at $t \rightarrow \infty$ (steady state creep conditions), respectively. The crack tip stress field, at the initial conditions $(t=0)$, should follow HRR field $[10,11]$ and $D$ is calculated as follows:

$$
D \equiv\left(\frac{\sigma_{y y}}{\sigma_{0}}\right)_{t=0}=\left[\frac{J(0)}{I_{m} \cdot A \cdot \sigma_{0}^{m+1} \cdot r}\right]^{\frac{1}{m+1}} \cdot \widetilde{\sigma}_{y y}(m, \theta)
$$

where $r$ and $\theta$ denote polar coordinate at the crack tip. $I_{\mathrm{m}}$ is a constant that depends on plastic stress exponent $m$. At long times under steady state creep conditions, the crack tip stress field follows RR field [12] and $F$ is calculated as follows:

$$
F \equiv\left(\frac{\sigma_{y y}}{\sigma_{0}}\right)_{t \rightarrow \infty}=\left[\frac{C^{*}}{I_{n} \cdot B \cdot \sigma_{0}^{n+1} \cdot r}\right]^{\frac{1}{n+1}} \cdot \widetilde{\sigma}_{y y}(n, \theta),
$$

$I_{n}$ is a constant that depends on creep stress exponent $n$.

Eq. (9) has the same form as Eq. (7), but plastic correction factor is different. In the case of $m=n$, these two equations become equal.

Based on Eqs. (10) and (11), Kim et al. [13] have also proposed an equation to predict crack-tip stress fields under transient creep.

\section{$4 \quad$ Results and discussion}

In order to compare the FE results of elastic-plasticcreep analyses under load control with the Eq.(9) for estimating $C(t)$, it was necessary to determine values of plasticity factor $\phi^{\prime}$. Determined FE values of $J(0)$ and $C^{*}$ presented in Tab. 2 were used for calculation of $F$ and $D$ values. In the case of $m=n$, values of $\phi$ in Eq. (7) and $\phi$ ' in Eq. (9) are equal.

Table 2 Values of $C^{*}$ and $J(0)$ obtained using FE analysis

\begin{tabular}{|c|c|c|c|c|c|c|}
\hline & \multicolumn{3}{|c|}{$C^{*}, \mathrm{MPa} \cdot \mathrm{mm} / \mathrm{h}(0), \mathrm{MPa} \cdot \mathrm{mm}$} \\
\cline { 2 - 7 } & $L_{\mathrm{r}}=0,4$ & $L_{\mathrm{r}}=0,8$ & $L_{\mathrm{r}}=1,0$ & $L_{\mathrm{r}}=0,4$ & $L_{\mathrm{r}}=0,8$ & 22,39 \\
\hline$m=n=5$ & 0,14 & 9,21 & 35,21 & 4,95 & 41,58 \\
\hline$m=n=10$ & 0,13 & 260,52 & 3033,00 & 4,89 & 4,23 & 40,14 \\
\hline$m=5 ; n=10$ & 0,13 & 260,52 & 3033,00 & 4,95 & 22,39 & 41,58 \\
\hline$m=10 ; n=5$ & 0,14 & 9,21 & 35,21 & 4,89 & 21,23 \\
\hline
\end{tabular}

The FE results of elastic-plastic-creep analyses under load control compared with $C(t)$ estimation Eq. (9) are shown in Fig. 4 and Fig. 5. It can be seen that Eq. (9) is a pretty good prediction for $C(t) / C^{*}$ relaxation curves. It can be seen that in few cases the Eq. (9) gives slightly more conservative result than FE analysis.

\section{Conclusion}

Detailed FE transient creep analyses have been performed for high-constraint $C(T)$ specimen geometry. Both elastic-creep and elastic-plastic-creep behavior under load control were considered. The power-law plastic and power-law creep behavior of the investigated material was assumed. In the case of initial plasticity, $m=$ $n$ and $m \neq n$ were analyzed, where $m$ and $n$ are the 
plasticity and creep stress exponents, respectively. The effect of the level of initial plasticity on transient creep is analyzed by systematically varying the magnitude of the initial step-load. Comparisons have been performed between the FE computed $C(t)$ values and estimation equation. It has been found that the estimation equation provides fairly good agreement with the FE results, even when $m \neq n$. Slight differences between FE results and estimation equation are the result of the constraint effect.
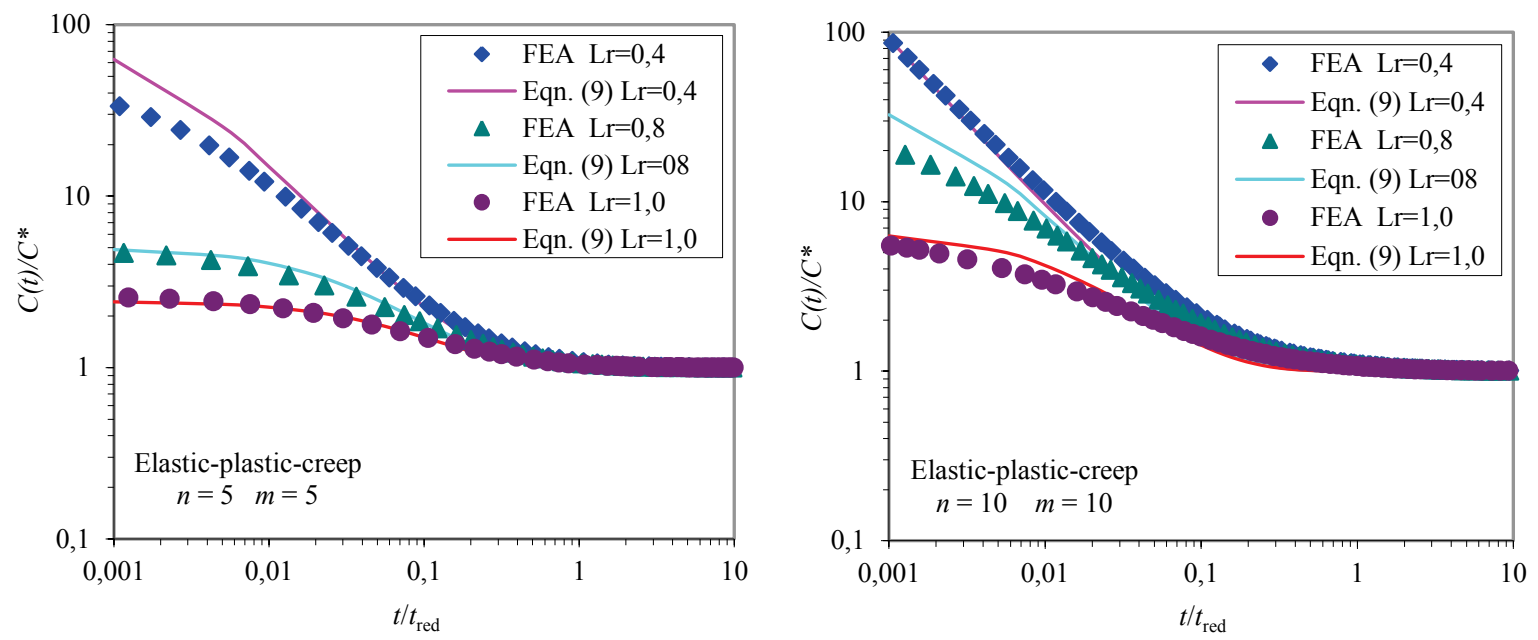

Figure 4 Comparison of FE results for $C(t) / C^{*}$ with estimation Eq. (9) in the case $m=n$
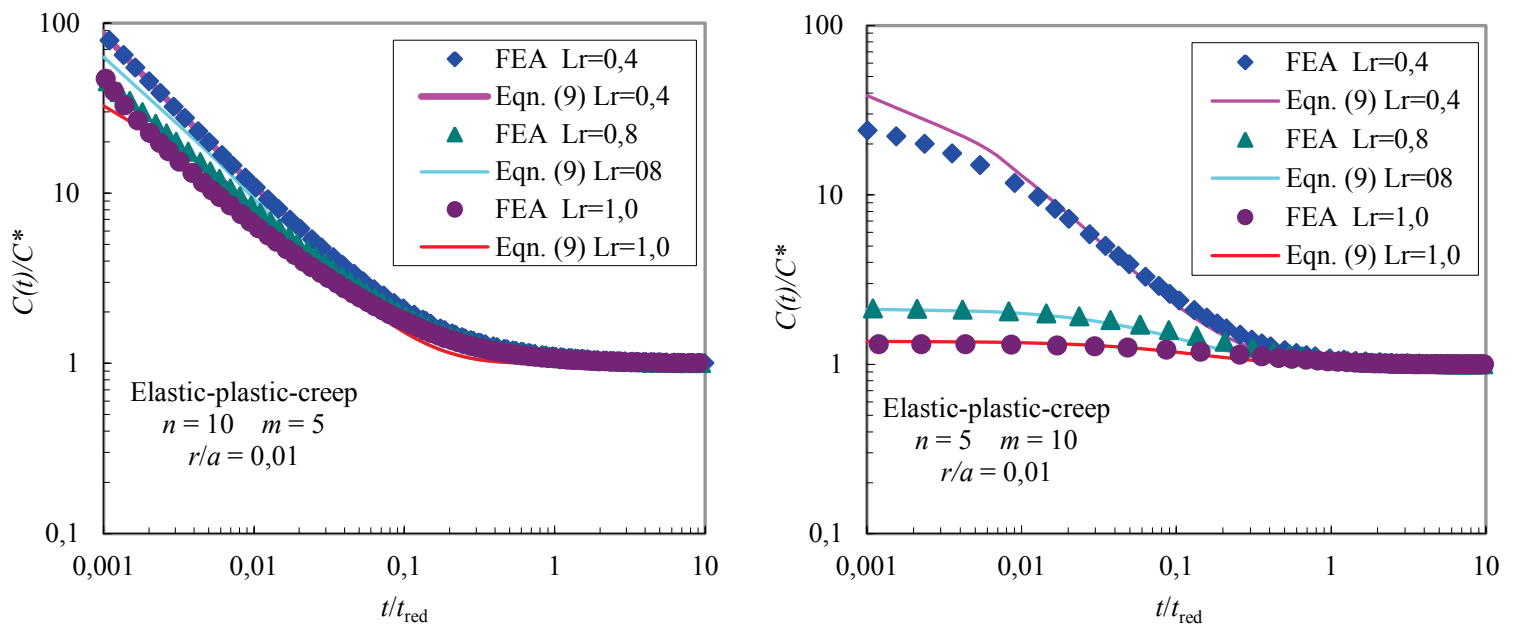

Figure 5 Comparison of FE results for $C(t) / C^{*}$ with estimation Eq. (9) in the case $m \neq n$

\section{References}

[1] Riedel, H. Fracture at high temperature. Springer-Verlag, Berlin, 1987. DOI: 10.1007/978-3-642-82961-1

[2] Ainsworth, R. A.; Budden, P. J. Crack tip fields under nonsteady creep conditions - I. Estimates of the amplitudes of the fields. // Fatigue Fract. Eng. Mater. Struct. 13, (1990), pp. 263-276. DOI: 10.1111/j.1460-2695.1990.tb00598.x

[3] Joch, J.; Ainsworth, R. A. The Effect of geometry on the development of creep singular fields for defects under stepload controlled loading. // Fatigue Fract. Eng. Mater. Struct. 15, (1992), pp. 229-240. DOI: 10.1111/j.14602695.1992.tb01266.x

[4] Lee, H. S.; Kim D. J.; Je, J. H.; Kim, Y. J.; Ainsworth, R. A.; Budden, P. J.General estimation equation of transient $\mathrm{C}(\mathrm{t})$ under load and displacement control. // 21st European Conference on Fracture, ECF21, 20-24 June 2016, Catania, Italy. DOI: 10.1016/j.prostr.2016.06.105

[5] Lee, S. D.; Lee, H. S.; Lee, M. W.; Kim, Y. J.; Ainsworth, R. A.; Dean, D. W. The influence of plastic material property equations on the initial $\mathrm{C}(\mathrm{t})$ and $\mathrm{J}(\mathrm{t})$ in elasticplastic-creep FE analysis. // 21st European Conference on
Fracture, ECF21, 20-24 June 2016, Catania, Italy. DOI: 10.1016/j.prostr.2016.06.109

[6] ABAQUS User's Manual. Version 6.10 Dassault Systems Simulia Corp., Providence, RI, USA.

[7] Tada, H.; Paris, P.; Irwin, G. The stress analysis of cracks handbook, Paris Productions Inc. St. Louis, Missouri, 1985.

[8] Kumar, V.; German, D.; Shih C. F. An engineering approach for elastic-plastic fracture analysis, EPRI Report NP-1931, 1981.

[9] Kim, Y. J.; Dean, D. W.; Budden, P. J. Finite element analysis to assess the effect of initial plasticity on transient creep for defects under mechanical loading. // International Journal of Pressure Vessels and Piping. 78, 11-12(2001), pp. 1021-1029. DOI: 10.1016/S0308-0161(00)00079-X

[10] Huchinson, J. W. Singular Behavior at End of a Tensile Crack Tip in a Hardening Material. // J. Mech. Phys. Solids. 16, (1968), pp. 13-31. DOI: 10.1016/0022-5096(68)90014-8

[11] Rice, J. R.; Rosengren, G. F. Plane Strain Deformation near a Crack Tip in a Power-Law Hardening Material. // J. Mech. Phys. Solids. 16, (1968), pp. 1-12. DOI: 10.1016/00225096(68)90013-6 
[12] Riedel, H.; Rice, J. R. Tensile Cracks in Creeping Solids. // ASTM STP 700, Philadelphia. (1980), pp. 112-130.

[13] Kim, D. J.; Lee, H. S.; Je, J. H.; Kim, Y. J.; Ainsworth, R. A.; Budden, P. J. Characterization of elastic-plastic-creep crack-tip stress fields under load and displacement control, 21st European Conference on Fracture, ECF21, 20-24 June 2016, Catania, Italy. DOI: 10.1016/j.prostr.2016.06.107

\section{Authors' addresses}

Dr. sc. Marko Katinić, Lecturer

College of Slavonski Brod, Technical Department, Dr. Mile Budaka 1, 35000 Slavonski Brod, Croatia

E-mail: marko.katinic@vusb.hr

\section{Dr. sc. Dražan Kozak, Full Professor}

Josip Juraj Strossmayer University of Osijek,

Mechanical Engineering Faculty in Slavonski Brod,

Trg Ivane Brlić Mažuranić 2, 35000 Slavonski Brod, Croatia

E-mail: dkozak@sfsb.hr

Dr. sc. Pejo Konjatić, Assistant Professor

Josip Juraj Strossmayer University of Osijek,

Mechanical Engineering Faculty in Slavonski Brod,

Trg Ivane Brlić Mažuranić 2, 35000 Slavonski Brod, Croatia

E-mail: Pejo.Konjatic@sfsb.hr 